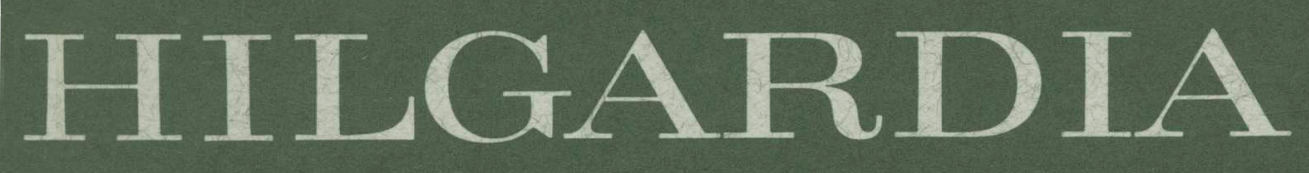

A JOURNAL OF AGRICULTURAL SCIENCE PUBLISHED BY THE CALIFORNIA AGRICULTURAL EXPERIMENT STATION

Volume 34, Number 3 - March, 1963

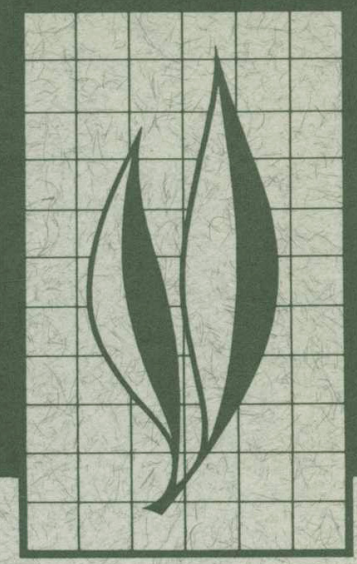

\title{
Pot Experiments Related to the Peach Replant Problem
}

A. E. Gilmore

UNIVERSITY OF CALIFORNIA DIVISION OF AGRICULTURALSCIENCES 


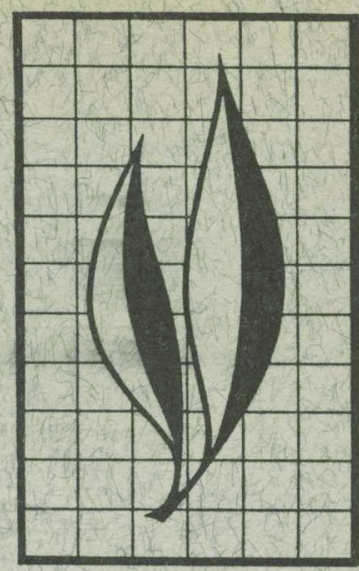

Composting of peach-root substances with two different soils in pot cultures did not prove to be a reliable method of simulating the peach replant problem though peach-root wood sometimes hindered nitrogen availability and in one experiment other root substances depressed the growth of peach seedlings. Successive plantings in pots of these soils did produce the depression. Soil fumigation was an ineffective treatment but steaming effected a partial recovery.

A third soil, less fertile than the other two, did not exhibit the replant depression but was injured by steaming.

\section{THE AUTHOR:}

A. E. Gilmore is Specialist in the Experiment Station, Department of Pomology, Davis. 


\section{Pot Experiments Related to the Peach Replant Problem ${ }^{1}$}

IN A PREVIOUS STUDY of the specific peach replant problem it was demonstrated that the addition of peach-root bark, or its dried alcoholic extract, to small peach seedlings in sand culture, could cause severe injury to the seedlings (Proebsting and Gilmore, 1940). Hilderbrand (1945) also showed stunting of peach trees in sand cultures containing peach roots. Havis and Gilkenson (1947), using 3-gallon sand cultures and a circulating nutrient solution of 18 liters, found no injury to the growth of 1-year-old budded nursery stock, or to very young peach seedlings when peach roots or peach-root substances were included in the cultures.

Hirai et al. (1957) found inhibition of peach seedlings due to addition of peach-root bark to the culture medium. Seedlings grown in bark and soil composts which had been heated after mixing did not show growth depression, but the depressive effect of the bark was not lessened by fumigation of the compost with formalin or carbon bisulfide.

Hirano (1957), in experiments using 1-year-old peach trees in pot culture, produced no inhibiting effect by the addition of peach "rootlets." However, when the experiment was repeated the following year, apparently using larger quantities of rootlets, marked retardation of growth was observed.

Puzzling differences of this sort among the results of various workers or among the results of various experiments of the same worker, are characteristic of the study of the specific peach replant problem. Similarly, a great variability results when peach trees are replanted in commercial fields.

The pot experiments reported here had the initial objective of confirming in soil culture the harmful effects of peach-root bark previously noted in sand cultures and of identifying the fraction responsible for the injury. Comparisons were also to be made with composts of other materials.

As the experiments continued, observations were made on the effects of repeated cropping of pots with peach seedlings, and attempts were made to alleviate the replant problem thus produced.

\section{MATERIALS}

Pots: These were cans of about 14 liters capacity, $24 \mathrm{~cm}$ in diameter and $32 \mathrm{~cm}$ high.

Soils: No. 20-Yolo loam collected from non-peach locations on the University fields at Davis.

No. 26-Hanford sandy loam from the bottoms on the north side of the

\footnotetext{
${ }^{1}$ Received for publication August 8, 1962.
} 
American River east of Sacramento. All collections of this soil were taken from a single surface location in a field where a peach replanting had shown poor performance.

No. 27-Hanford loamy fine sand from the bottoms on the south side of the American River east of Sacramento. All samples were collected from a single location under natural cover.

Judged by growth of first plantings of peach seedlings in pots, soil 20 was the most fertile, soil 27 the least, and soil 26 intermediate.

This lesser fertility of soil 26 compared with soil 20 probably cannot be attributed to its collection from a replant situation as previous work has demonstrated that such soils do not necessarily show the replant depression when first planted to peaches in pot culture (Proebsting and Gilmore, 1940). Water: Water used for the cultures was a class-one agricultural water from shallow wells at the Experiment Station.

Nitrogen Source: Ammonium nitrate, with the exception of calcium nitrate in experiment 8 , was used as a nitrogen supply.

Spray Materials: Various sprays and dusts were used as appropriate for the control of mites and mildew.

Soil Fumigants: Dichloropropene, carbon bisulfide, white gasoline, chlorobromopropene, and ethylene dibromide, were at times used as soil fumigants in attempts to restore productivity to soils which had become unproductive in pot culture.

Composting Materials: Roots and root fractions of peach, root barks of various other Prunus species including almond, myrobalan, apricot, cherry, as well as trunk bark of peach and hemlock, and filter paper were used in preparing composts. Roots were obtained from near the crowns of pulled trees and either stored as pieces of whole root or after separating into wood and bark. Usually the roots or their parts were air-dried and stored at room tem- perature, but one collection of peach root material was frozen and stored at $-10^{\circ} \mathrm{C}$. Variety of the rootstocks from which peach-root collections were made was not usually known but can be assumed to be Lovell seedlings, except for one collection which, as indicated in the tables, was Muir seedlings.

After drying, the peach-root bark was additionally fractionated by solvent and chemical means. The following eight fractions were used to prepare seven composting materials based on peach roots or their parts:

1. Whole peach root.

2. Peach-root wood.

3. Peach-root bark.

4. $\mathrm{RAx}$ - the residue of peach-root bark after grinding and extracting with cold 95 per cent ethyl alcohol.

5. Ax-the dried alcohol extract of peach-root bark. This was dried by reduction in vacuum, below $45^{\circ} \mathrm{C}$, to a thick syrup which was then thinly spread on a glass plate until brittle. The scales obtained by scraping the material from the plate were ground in a mortar and exposed to air for some weeks to insure removal of the solvent.

6. BA1-a fraction precipitated from Ax as follows: A quantity of Ax was mixed with an equal weight of water and brought into solution by stirring and mixing. A clear, deep-red syrupy solution resulted which from its clarity in thin layers appeared to be a true solution. This was then poured, with stirring, into a weight of water equal to about nine times the weight of solute, so that the final weight of water was about ten times that of the solute. A quantity of reddish-brown material was precipitated as a flocculent mass by this dilution. The precipitate was filtered on a Büchner funnel and washed with two to three portions of distilled water.

7. BA2 - a saturated solution of neutral lead acetate, $\mathrm{Pb}\left(\mathrm{C}_{2} \mathrm{H}_{3} \mathrm{O}_{2}\right)_{2}$, was added to the filtrate from the BA1 preparation to precipitate an additional fraction which was recovered on a Büchner funnel and transferred to 
TABLE 1

COMPOSITION OF PEACH ROOTS

(Dry-weight basis)*

\begin{tabular}{|c|c|c|c|c|}
\hline \multirow{2}{*}{ Weight } & \multirow{2}{*}{ Fraction } & \multicolumn{3}{|c|}{ Percentage of } \\
\hline & & Whole root & Bark & $A x$ \\
\hline$g m$ & & & & \\
\hline 500 & Root. & 100 & & \\
\hline 305 & Wood.. & 61 & & \\
\hline 195 & Bark. . & 39 & 100 & \\
\hline 118.9 & .................... & 23.8 & 61 & \\
\hline 76.1 & Ax. & 15.2 & 39 & 100 \\
\hline 27.9 & BA1.. & 5.6 & 14.3 & 36.6 \\
\hline 35.9 & BA2. & 7.2 & 18.4 & 47.2 \\
\hline 12.3 & BA3 (Incompletely dried) $\ldots \ldots \ldots \ldots \ldots \ldots \ldots \ldots$ & 2.4 & 6.3 & 16.2 \\
\hline
\end{tabular}

* Values obtained by proportionate distribution of losses in a procedure to the components.

95 per cent ethyl alcohol. The precipitated organic materials were freed of lead with hydrogen sulfide in 95 per cent alcohol, concentrated in a vacuum still at below $45^{\circ} \mathrm{C}$, and dried on a glass plate.

8. BA3-the filtrate from the BA2 precipitation was cleared of lead by saturating with hydrogen sulfide, and the filtrate from the lead sulfide reduced in a vacuum still below $45^{\circ} \mathrm{C}$. After the solution was reduced to a high concentration, absolute ethyl alcohol was introduced and distilled off three or four times to reduce the amount of water and acetic acid present in the concentrate as the result of the lead acetate clarification. The concentrate so produced was a thick syrupy mass which was hydroscopic and difficult to dry, although thin layers could be dried in a dessicator. Thick layers crusted and could be dried only after very long periods of time.
A representative composition of peach roots, gathered in the fall, according to the described fractions, is shown in table 1 . The BA1 and BA2 fractions are tannins of the phlobotannin type and apparently vary only in their state of aggregation, the BA1 fraction being the heavier polymer. Progressive polymerization of these tannins occurs in aqueous solution, BA1 being slowly precipitated from aqueous solutions of extracts containing BA2. Dried preparations of BA2 can rarely be completely redissolved in water and the amount redissolved is dependent on using a small rather than a large amount of water, the optimum being in the range of $20 \mathrm{gm}$ of $\mathrm{BA} 2$ to $80-100$ cc of water.

The BA3 fraction, from its method of preparation, would be expected to be mostly carbohydrates and glucosides, or their degradation products.

\section{METHODS}

Growth measurements, as dry.weight of tops, or height measurements in experiment 2 , were made on peach seedlings grown for a season in pots of soil prepared by composting, or by having had peach seedlings grown in them in previous seasons. At times, various fumigants or steam treatments were used in attempts to restore fertility where this had been reduced by previous cropping.

With the exception of experiment 1 , which was done in a greenhouse, all experiments were carried out in a lathhouse shaded from the afternoon sun by a row of trees, and were subject to year-to-year climatic variations.

Seedlings for the tests were grown 
in the greenhouse or lathhouse, in small pots of steamed soil, till transplanted to the test pots. The seeds used were of the Lovell variety and were afterripened under aseptic conditions as previously described (Gilmore, 1950). In some years it was possible to select uniform seedlings and in others it was necessary to use seedlings of varying heights, in which case, after grading, a uniform distribution of the various sizes was made to the different sets of pots in the experiment.

Growing periods of seedlings prior to and after transplanting to the test pots varied somewhat from year to year. Transplanting dates fell between May 1 and June 16 and seedling heights varied from 10 to $40 \mathrm{~cm}$. These differences are indicated in the tables which also show the number of days between transplanting and harvest of the tops. The latter values are not accurate indications of growing periods in the pots. Harvest was made at irregular times late in October or early November after the cessation of growth, but before leaf fall. These differences in growing times and conditions are of little importance when comparisons are made between sets of trees grown in the same year. It will be apparent that where comparisons are made between trees grown in successive years, that these differences are likewise minor in comparison to other factors affecting growth.

There was no sanitary control between pots or groups of pots containing soils of different series. Ample opportunity for transfer of soil organisms among the pots was afforded on the preparation bench, by transplanting and weeding tools, by watering procedures, and by birds which worked on the surface of the pots.

In experiments 1-4 the substances used in the tests were mixed with sufficient soil to fill the pots to within 2.5$5.0 \mathrm{~cm}$ of the top. In some tests the trees were planted soon after preparing the composts and in others a delay of weeks occurred, as indicated in the tables. Root and bark material was applied in various physical conditions. Unless specified as fresh or frozen, the material was taken from dry storage. Material designated as fresh was composted soon after collection and that designated as frozen was taken from material stored in fresh condition at approximately $-10^{\circ} \mathrm{C}$.

In experiments 1 and 2 application of the fractions of peach root were made at rates approximating the amounts present in $500 \mathrm{gm}$ of whole, dry roots; exceptions being root wood, experiment 2 , where insufficient material was available, and $\mathrm{BA} 3$, experiment 2, where application was made in greater amount to insure that the weight of solids in the incompletely dried mass was at least equivalent to that occurring in $500 \mathrm{gm}$ dry roots. In experiments 3 and 4 , additions of the composting substances were made at uniform rates, 190-200 gm per pot, dry weight basis, with the exception of $\mathbf{A x}$ which was used at its rate of occurrence in $500 \mathrm{gm}$ of dry roots.

In experiment 4 and subsequent experiments, plantings were made in pots of soil previously used to grow peach seedlings. In these pots the old root systems were usually killed prior to replanting by cutting off the stump below the crown, or by other means; but in some cases the short stumps (1-2 cm high) remaining from the previous harvest were allowed to produce one to three sprouts which were pruned back occasionally to maintain the old root systems in a living but not vigorous condition. These pots are designated as "old roots alive." Later in experiment 8 , new shoots were allowed to grow for a season on the old root systems without the inclusion of a new tree in the pot; reference to these one-season shoots on the previous year's root system is made by "2nd year shoot."

In attempts to restore fertility of pots, which had become unproductive as the result of growing peach seedlings 
in them, the following treatments were tried: Five ce of dichloropropene or carbon bisulfide, or 15 cc of non-leaded gasoline injected $12 \mathrm{~cm}$ below the soil surface 48 days before planting, experiment 5 . Thirty ce of ethylene dibromide or chlorobromopropene applied $12 \mathrm{~cm}$ below the soil surface after which a polyethylene cover was tied over the pot for 48 hours and then the soil was exposed to air in shallow trays for 15 days with frequent stirring, experiment 7. Steaming the pots three hours at 12 $\mathrm{lb}$ and nine hours at $15 \mathrm{lb}$. Submerging the pots in a tank of water for 90 days in an attempt to produce anaerobic decay of the roots and residues of previous plantings. Screening to remove old root systems. Submersion did not accomplish its purpose as numbers of the stumps sprouted after removal from the tank.

Checks were sometimes employed in multiple sets to get some idea of the variation to be expected among sets of such small numbers. Each numbered experiment refers to seedlings grown in a particular year and the experiments are numbered in the order in which they were done. As additional pots of soil were introduced into the experiments, previously used pots were discarded to keep their number within reasonable bounds. It is for this reason that so few replanted pots of the first soil used (No. 20) were available in the latter experiments.

\section{RESULTS AND DISCUSSION}

\section{Composts}

The details of experiments 1-4 are given in tables 2-5 summarized in table 6 , where the results for selected compost treatments are expressed as percentage of their checks in order to facilitate comparison.

Experiment 1: The first experiment indicated that peach-root substances were harmful composting agents for pot soils used to grow peach seedlings, but puzzling features of these results appeared to raise more questions than they answered.

From previous work with sand cultures (Proebsting and Gilmore, 1940) it was expected that the bark or some fraction of the alcohol-soluble extract would prove most injurious. Yet it was the root wood which showed the greatest injury. Likewise, a question was raised by the much greater injury which occurred through the use of powdered bark when compared with bark applied in chunks. Poor performance of $\mathrm{Ax}$ and the mixture of $\mathrm{BA} 1$ and $\mathrm{BA} 2$ was expected but poor performance of $\mathrm{RAx}$ was not.

If poor performance of peach seedlings in composts of root substances was dependent on some poisonous root fraction, it would be expected, provided a good separation could be made, that the poisonous fraction would produce an inhibition somewhat of the order of the whole peach root, and that other fractions would show little effect. Some modification of this supposition would have to be made to account for the effect of one component on another if solution rates were involved, or if through the action of the soil flora a material were altered with regard to its toxicity. It is thought from laboratory observations that rate of breakdown or decomposition of various components of peach root may be influenced by the presence of other components. Peachroot wood or alcohol-extracted bark, if stored in a moist condition at room temperature, is rapidly attacked by molds. Moist peach root bark or an alcoholic extract of bark, when converted to water solution may be stored without precaution. The BA3 fraction is so susceptible to organism attack that it cannot be handled in water solution without strict asepsis. Despite these laboratory observations peach roots do decompose in the soil, but nothing is 
TABLE 2

COMPOSTING EFFECT ON AVERAGE DRY WEIGHT OF PEACH SEEDLING TOPS (Pot experiment 1)*

\begin{tabular}{|c|c|c|c|c|c|c|}
\hline \multirow{2}{*}{$\begin{array}{l}\text { Rank } \\
\text { of set }\end{array}$} & \multicolumn{2}{|l|}{ Treatment } & \multirow{2}{*}{$\begin{array}{c}\text { Arithm. } \\
\text { means }\end{array}$} & \multirow{2}{*}{$\begin{array}{l}\text { No. of } \\
\text { pots }\end{array}$} & \multirow{2}{*}{$\begin{array}{l}\text { Standard } \\
\text { deviation }\end{array}$} & \multirow{2}{*}{$\begin{array}{c}\text { Coefficient } \\
\text { of variation }\end{array}$} \\
\hline & Composting material & Amount & & & & \\
\hline & & $g m$ & $g m$ & & $g m$ & per cent \\
\hline 1 & Check. & $\ldots$ & 61.6 & $\mathbf{5}$ & 4.0 & 6.5 \\
\hline 2 & BA3... & 20 & 59.2 & 5 & 2.4 & 4.0 \\
\hline 3 & Check................ & $\ldots$ & 53.8 & 5 & 6.9 & 12.8 \\
\hline 4 & Peach-root bark (chunks). . & 194 & 50.6 & 5 & 12.8 & 25.3 \\
\hline 5 & Whole peach root (chunks). & 500 & 40.0 & 5 & 13.2 & 33.0 \\
\hline 6 & RAx Muir $\ldots \ldots \ldots \ldots \ldots \ldots \ldots$ & 112 & 28.0 & 5 & 13.2 & 47.1 \\
\hline 7 & $\mathbf{A x} \ldots \ldots \ldots$ & 81 & 27.3 & 5 & 18.9 & 69.2 \\
\hline 8 & Peach-root bark (powder) . . . . . . . & 194 & 27.0 & 5 & 7.0 & 25.9 \\
\hline 9 & Proportional mixture of $\mathrm{BA} 1+\mathrm{BA} 2$ & 58 & 18.7 & 5 & 7.3 & 39.1 \\
\hline 10 & Peach-root wood (chunks).......... & 306 & 12.2 & 5 & 6.4 & 52.4 \\
\hline
\end{tabular}

* Soil 20 from greenhouse bins. Composting done just prior to transplanting with 7.5 cm seedlings February 2 which were then grown 163 days in the greenhouse. No nitrogen added.

TABLE 3

COMPOSTING EFFECT ON AVERAGE HEIGHT OF PEACH SEEDLINGS (Pot experiment 2)*

\begin{tabular}{|c|c|c|c|c|}
\hline \multirow{2}{*}{$\begin{array}{l}\text { Rank } \\
\text { of set }\end{array}$} & \multicolumn{2}{|l|}{ Treatment } & \multirow{2}{*}{$\begin{array}{l}\text { No. per } \\
\text { set }\end{array}$} & \multirow{2}{*}{ Height } \\
\hline & Composting material & Amount & & \\
\hline & & $g m$ & & $\mathrm{~cm}$ \\
\hline 1 & Ax Muir. . & 81 & $\mathbf{5}$ & 69 \\
\hline 1 & 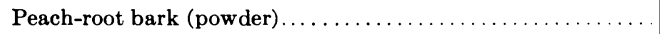 & 194 & $\mathbf{5}$ & 69 \\
\hline 1 & 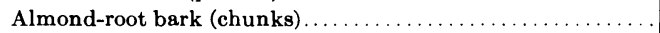 & 190 & 5 & 69 \\
\hline 1 & 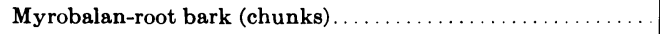 & 190 & 5 & 69 \\
\hline 1 & Apricot-root bark (chunks) ............. & 190 & 5 & 69 \\
\hline 1 & Hemlock bark (powder)........ & 190 & 5 & 69 \\
\hline 1 & Filter paper (shredded) . . . . . & 190 & 5 & 69 \\
\hline 2 & Cherry-root bark (chunks).... & 190 & 5 & 66 \\
\hline 2 & Whole peach roots (chunks) .. & 500 & 5 & 66 \\
\hline 2 & Peach-root bark (chunks).... & 194 & 5 & 66 \\
\hline 2 & Proportional mixture BA1 + BA2 Muir....... & 58 & 5 & 66 \\
\hline 2 & 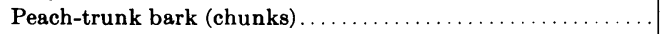 & 190 & 5 & 66 \\
\hline 3 & 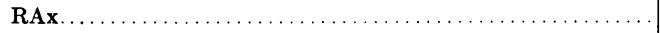 & 112 & 5 & 63 \\
\hline 3 & Peach-root wood (chunks) $\ldots \ldots \ldots \ldots \ldots \ldots \ldots \ldots \ldots \ldots \ldots \ldots \ldots \ldots \ldots \ldots \ldots$ & 100 & 5 & 63 \\
\hline 4 & 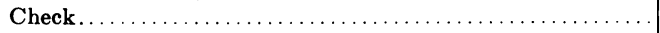 & $\ldots$ & 5 & 60 \\
\hline
\end{tabular}

* Soil 20 from field collection. Composting done 36 days prior to transplanting with $40 \mathrm{~cm}$ seedlings June 3 , which were then grown 81 days in the lathhouse. Four $\mathrm{gm}$ of ammonium nitrate per pot 13 days prior to transplanting.

known of the rate of decomposition or whether some components may be more slowly attacked than others. In the case of the whole root it is not known whether the bark may exert a retarding influence as compared to the wood with bark removed.

Experiment 2: Consideration was given to the possibility that the poor performance of peach-root wood was a nitrogen suppression effect. Therefore, in setting up the second experiment, 4 gm of ammonium nitrate were added to all pots, prior to transplanting, in the hope of separating toxic effects from nitrogen suppression effects if such existed. The experiment was expanded to include root barks of other Prunus species, a bark with high tannin content (hemlock) and a pure source of cellulose (filter paper).

In this experiment (table 3 ) all com- 
posted sets grew vigorously and outperformed the single check set. Though the RAx treatment and peach-root wood at the lesser rate of application comprised the poorest group of the composts, this would seem to be of little significance since they did outperform the check, and because differences for the entire planting were small.

A decision was made not to harvest this experiment but to allow the trees to grow a second year in the pots to see if a delayed reaction to the treatments would occur. It did not. Growth the following year continued excellent.

Experiment 3: In experiment 3 a change was made to soil 26 , and composting materials were employed at a constant dry-weight basis equivalent of $190 \mathrm{gm}$ per pot with the exception of Ax applied at $81 \mathrm{gm}$ per pot. As a result of the previous two experiments the question of nitrogen suppression was now uppermost. Nitrogen application was delayed till sometime after transplanting so some idea of performance could be had, and the effect of the delayed nitrogen application appraised. Three sets of checks were used to get some idea of the spread among sets comprised of such small numbers.
Fifty days after transplanting it appeared that all treatments except peach-root wood were performing as well as or better than the checks. Trees in the peach-root wood composts showed severe injury. This set had made little growth; terminal buds had formed, the leaf color was quite yellow, and it was apparent that without intervention the seedlings would not survive. At this time $4 \mathrm{gm}$ of ammonium nitrate were added to the root-wood set as well as other sets showing any yellowish cast of leaves. Some days later, after opportunity to observe response was had, the remaining sets were treated.

The response of the root-wood compost was remarkable. Within a week the terminal buds had broken and growth resumed, but after such severe injury did not regain normal vigor. The only other set to show response to the heavy nitrogen application was the hemlock-bark set which developed a better leaf color. No influence on shoot growth was noted.

Leaf analyses made on the harvested material at the end of the experiment showed the peach-root wood set to have the highest values for both nitrogen and phosphorus at 3.1 per cent and .24

TABLE 4

COMPOSTING EFFECT ON AVERAGE DRY WEIGHT OF PEACH SEEDLING TOPS (Pot experiment 3)*

\begin{tabular}{|c|c|c|c|c|c|c|}
\hline \multirow{2}{*}{$\begin{array}{l}\text { Rank } \\
\text { of set }\end{array}$} & \multicolumn{2}{|l|}{ Treatment } & \multirow{2}{*}{$\underset{\text { means }}{\text { Arithm. }}$} & \multirow{2}{*}{$\begin{array}{c}\text { No. of } \\
\text { pots }\end{array}$} & \multirow{2}{*}{$\begin{array}{l}\text { Standard } \\
\text { deviation }\end{array}$} & \multirow{2}{*}{$\begin{array}{l}\text { Coefficient } \\
\text { of variation }\end{array}$} \\
\hline & Composting materials & Amount & & & & \\
\hline & & $g m$ & $g m$ & & $g m$ & per cent \\
\hline 1 & Apricot-root bark (chunks). & 190 & 73.1 & $\mathbf{5}$ & 8.7 & 11.9 \\
\hline 2 & Peach-root bark (frozen chunks). & 350 & 63.8 & 5 & 7.8 & 12.3 \\
\hline 3 & Almond-root bark (chunks) ..... & 190 & 59.1 & 5 & 9.7 & 16.4 \\
\hline 4 & Myrobalan-root bark (chunks) & 190 & 54.0 & 5 & 8.2 & 15.2 \\
\hline 5 & Hemlock-trunk bark (powder). & 190 & 52.5 & $\mathbf{5}$ & 8.2 & 15.7 \\
\hline 6 & Cherry-root bark (chunks)..... & 190 & 49.1 & 5 & 5.4 & 10.9 \\
\hline 7 & Peach-root bark (chunks).... & 190 & 46.5 & 5 & 7.3 & 15.7 \\
\hline 8 & Check............... & $\cdots$ & 46.4 & $\mathbf{5}$ & 7.9 & 17.0 \\
\hline 9 & $\mathbf{A x} \ldots \ldots$ & 81 & 45.3 & 5 & 12.4 & 27.3 \\
\hline 10 & Check................ & $\ldots$ & 44.8 & 5 & 7.1 & 15.8 \\
\hline 11 & Whole peach root (chunks).. & 190 & 43.7 & 5 & 7.2 & 16.4 \\
\hline 12 & Check.............. & $\ldots$ & 42.4 & $\mathbf{5}$ & 5.9 & 13.8 \\
\hline 13 & Peach-trunk bark (chunks).. & 190 & 40.9 & 5 & 7.6 & 18.4 \\
\hline 14 & Peach-root wood (frozen chunks) & 350 & 17.8 & 5 & 5.9 & 33.3 \\
\hline
\end{tabular}

* Soil 26. Composting done 36 days prior to transplanting with $27-35 \mathrm{~cm}$ seedlings May 1 , which were then grown 170 days in the lathhouse. Four gm of ammonium nitrate per pot 50 days after transplanting. 
TABle 5A

COMPOSTING EFFECT ON AVERAGE DRY WEIGHT OF PEACH SEEDLING TOPS (Pot experiment 4$)^{*}$

\begin{tabular}{|c|c|c|c|c|c|c|c|}
\hline \multirow{2}{*}{$\begin{array}{c}\text { Rank } \\
\text { of } \\
\text { set }\end{array}$} & \multicolumn{3}{|l|}{ Treatment } & \multirow{2}{*}{$\begin{array}{l}\text { Arithm. } \\
\text { means }\end{array}$} & \multirow{2}{*}{$\begin{array}{l}\text { No. } \\
\text { of } \\
\text { pots }\end{array}$} & \multirow{2}{*}{$\begin{array}{l}\text { Standard } \\
\text { deviation }\end{array}$} & \multirow{2}{*}{$\begin{array}{c}\text { Coefficient } \\
\text { of } \\
\text { variation }\end{array}$} \\
\hline & Composting material & Amount & Compostg. & & & & \\
\hline & & $g m$ & days & $g m$ & & $g m$ & per cent \\
\hline 1 & Check steamed 8 hrs@ $12 \mathrm{lb}$. & $\ldots$ & $\ldots$ & 53.7 & 5 & 3.7 & 6.7 \\
\hline 2 & RAx Muir $\ldots \ldots \ldots \ldots \ldots$ & 190 & 67 & 50.4 & 5 & 11.1 & 22.0 \\
\hline 3 & Check steamed 3 hrs@ 12 lb...... & $\ldots$ & $\ldots$ & 49.5 & 5 & 4.2 & 8.4 \\
\hline 4 & Peach-root bark (frozen chunks). & 350 & 67 & 49.4 & 5 & 9.6 & 19.4 \\
\hline 5 & Peach-root wood (chunks) steamed & 190 & 67 & 48.1 & 5 & 58 & 120 \\
\hline 6 & Peach-root bark (fresh chunks) ..... & 350 & 150 & 47.0 & $\mathbf{5}$ & 3.2 & 6.8 \\
\hline 7 & Check $\ldots \ldots \ldots \ldots \ldots \ldots \ldots$ & $\ldots$ & $\ldots$ & 46.1 & 5 & 5.1 & 11.0 \\
\hline 8 & Check $\ldots \ldots \ldots \ldots \ldots \ldots \ldots$ & $\ldots$ & $\ldots$ & 44.6 & $\mathbf{5}$ & 4.2 & 9.3 \\
\hline 9 & Whole peach roots (fresh) ...... & 350 & 150 & 42.7 & 4 & 6.3 & 14.8 \\
\hline 10 & Peach-root bark (powder) .......... & 190 & 67 & 41.6 & 5 & 6.2 & 15.0 \\
\hline 11 & Check $\ldots \ldots \ldots \ldots \ldots \ldots \ldots \ldots$ & $\ldots$ & $\ldots$ & 41.4 & 5 & 4.5 & 10.9 \\
\hline 12 & Peach-root wood (fresh) $\ldots \ldots \ldots \ldots \ldots$ & 350 & 150 & 40.6 & 5 & 2.5 & 6.0 \\
\hline 13 & Check .................. & $\ldots$ & $\ldots$ & 40.1 & 5 & 5.6 & 14.0 \\
\hline 14 & Peach-root bark (chunks)... & 200 & 150 & 39.3 & 5 & 6.4 & 16.4 \\
\hline 15 & Peach-root wood (chunks) ......... & 190 & 67 & 38.7 & 5 & 2.6 & 6.7 \\
\hline \multirow[t]{2}{*}{16} & Peach-root wood (chunks) +100 gm & & & & & & \\
\hline & $\mathbf{A x} \ldots \ldots \ldots \ldots \ldots \ldots \ldots \ldots \ldots \ldots \ldots \ldots \ldots$ & 200 & 67 & 38.7 & 5 & 5.5 & 14.3 \\
\hline 17 & Peach-root wood (chunks) .......... & 200 & 150 & 34.2 & 5 & 5.8 & 17.1 \\
\hline
\end{tabular}

* Soil 26. Composting done about 150 days or 67 days before transplanting with $20 \mathrm{~cm}$ seedlings on June 7 , and then grown 157 days in the lathhouse. Four $\mathrm{gm}$ of ammonium nitrate per pot 27 days and again 73 days after transplanting.

TABLE 5B

REPLANTING AND TREATING EFFECTS ON AVERAGE DRY WEIGHT OF SEEDLING TOPS

(Pot experiment 4)

\begin{tabular}{|c|c|c|c|c|c|c|c|}
\hline \multirow{2}{*}{ Rank of set* } & \multicolumn{3}{|c|}{ Replanting } & \multirow{2}{*}{$\underset{\text { means }}{\text { Arithm. }}$} & \multirow{2}{*}{$\begin{array}{c}\text { No. } \\
\text { of } \\
\text { pots }\end{array}$} & \multirow{2}{*}{$\begin{array}{l}\text { Standard } \\
\text { deviation }\end{array}$} & \multirow{2}{*}{$\begin{array}{l}\text { Coefficient of } \\
\text { variation }\end{array}$} \\
\hline & $\begin{array}{l}\text { Age of root } \\
\text { system }\end{array}$ & $\begin{array}{l}\text { Condition of } \\
\text { root system }\end{array}$ & $\begin{array}{l}\text { Soil } \\
\text { type }\end{array}$ & & & & \\
\hline & years & & & $g m$ & & $g m$ & per cent \\
\hline 18. & 2 & Dead $\dagger$ & 20 & 25.4 & 5 & 5.8 & 22.9 \\
\hline 19. & 2 & Dead $\dagger$ & 20 & 25.3 & 5 & 4.2 & 16.8 \\
\hline 20 . & 2 & Living & 20 & 10.8 & 4 & 5.4 & 50.3 \\
\hline 21. & 2 & Living & 20 & 6.8 & 5 & 2.7 & 39.5 \\
\hline 22. & 1 & Dead & 26 & 19.0 & 5 & 2.2 & 11.3 \\
\hline 23 . & 1 & Living & 26 & 8.3 & 5 & 1.6 & 19.3 \\
\hline
\end{tabular}

* Continuation from table $5 \mathrm{~A}$.

† Steamed3 hrs@12 lb.

per cent respectively. Potassium at 3.0 per cent was 0.1 per cent below the highest value shown.

Two of three experiments now indicated that, of the composting materials used, all except peach-root wood were either ineffective or beneficial, and that the harmful effects of peach-root wood were at least in part due to the reduction of available nitrogen.

Experiment 4: In experiment 4 the composting experiments were continued (table 5A) and in addition some previously cropped pots, to be discussed later, were replanted (table 5B). Composting was done as previously, but the time between composting and transplanting was increased to test if a longer time allowed for decay of the composts had an effect. Some of the sets were prepared in a 2-week period approximately 150 days before trans- 
planting. Another series was prepared with materials available 67 days before transplanting. The steamed sets were autoclaved 28 days before transplanting. The first application of nitrogen was made 27 days after transplanting when poor leaf color was first noticeable. Nitrogen was again applied 73 days after transplanting to insure continuance of a high nitrogen level.

In this experiment there was even less evidence that the composting substances were responsible for any great harm to the seedlings. The 150-day compost of peach-root wood showed the least growth but the performance of this set was much better than the rootwood set of the previous year and only little worse than the poorest check. Peach-root wood compost which had been steamed was superior to any of the non-steamed checks. It would appear that for root wood, at least any harmful effects were due to nitrogen suppression through biological activity.

For all except the root-wood composts, three of the four experiments indicate that they were harmless or beneficial. Experiment 1, however, remains to raise the question of whether these materials are always innocuous. Here all composting materials showed some suppression of growth with the exception of the BA3 fraction. It might be argued that these pots, tested in the greenhouse, were subject to environmental conditions conducive to higher biological activity and that BA3, the exception, was added in a relatively small amount and so easily decomposed that its effects were dissipated in a relatively short time. Yet in experiment 3, where peach-root wood showed unmistakable evidence of nitrogen suppression, only the hemlock bark, of all the other sets, showed any suggestion of such an effect.

The question of modes and rates of decomposition of peach-root residues and their effects on subsequent plantings remain unanswered, but it seems, from these experiments, that the re- plant problem cannot be reliably simulated by means of peach-root composts.

\section{Replanting and Treating Effects}

As a part of experiment 4, some pots of soils 20 and 26 were replanted. Composting history of soil 20 is variable and unknown. Pots of experiment 2 in which vigorous growth had continued for two years were taken at random. Two sets of soil 20 were steamed to insure death of the roots and reduce biological activity, and in two sets the old root systems were maintained in a living condition. The pots of soil 26 had not been composted but were checks from experiment 3 . Old roots of one set in this soil were kept living.

Replanting was done in the presence of living roots versus dead roots of the previous planting with the thought that if toxic materials were released into the soil by the dead roots this would be prevented, or at least slowed in the case of the roots kept living. For both soils the growth of the replantings was roughly half the expectation for these soils where the old root systems were killed, but was reduced to a fifth or less when the replant was grown in the presence of a living root system of the previous planting. This additional retardation due to the presence of a living root system from a previous planting proved to be typical in subsequent replantings. The effect, as explained in Gilmore (1962), does not appear to be due to any interaction dependent on contact of the two root systems but simply to an insufficient volume of soil for the two plants.

Experiment 5: The following year, in experiment 5 (table 7 ), it was decided simply to replant the pots in the lathhouse using a different treatment (fumigant) or condition (old roots living or dead) for each pot of the sets as then constituted. The resulting reconstituted sets each contained 20 pots of soil 26 and 4 pots of soil 20 with the exception of the set treated with gasoline which had only three pots of soil 20 . 
TABLE 6

WEIGHTS OF COMPOSTING MATERIALS AND GROWTH OF PLANTINGS (Selected data from experiments 1 to 4 )

\begin{tabular}{|c|c|c|c|c|c|c|c|c|c|}
\hline \multirow{6}{*}{$\begin{array}{c}\text { Peach-root } \\
\text { composting } \\
\text { material and } \\
\text { condition }\end{array}$} & \multicolumn{4}{|c|}{ Soil 20} & \multicolumn{5}{|c|}{ Soil 26} \\
\hline & \multicolumn{2}{|c|}{ Experiment 1} & \multicolumn{2}{|c|}{ Experiment 2} & \multicolumn{2}{|c|}{ Experiment 3} & \multicolumn{3}{|c|}{ Experiment 4} \\
\hline & \multirow{3}{*}{$\begin{array}{l}\text { Com- } \\
\text { posting } \\
\text { materials } \\
\text { per pot }\end{array}$} & \multirow{3}{*}{$\begin{array}{l}\text { Average } \\
\text { weight } \\
\text { of } \\
\text { tops }\end{array}$} & \multirow{3}{*}{$\begin{array}{l}\text { Com- } \\
\text { posting } \\
\text { materials } \\
\text { per pot }\end{array}$} & \multirow{3}{*}{$\begin{array}{c}\text { Average } \\
\text { weight } \\
\text { of } \\
\text { tops }\end{array}$} & \multirow{3}{*}{$\begin{array}{c}\text { Com- } \\
\text { posting } \\
\text { materials } \\
\text { per pot }\end{array}$} & \multirow{3}{*}{$\begin{array}{c}\text { Average } \\
\text { weight } \\
\text { of } \\
\text { tops }\end{array}$} & \multirow{3}{*}{$\begin{array}{c}\text { Com- } \\
\text { posting } \\
\text { materials } \\
\text { per pot }\end{array}$} & \multicolumn{2}{|c|}{ Composting time } \\
\hline & & & & & & & & 150 days & 67 days \\
\hline & & & & & & & & \multicolumn{2}{|c|}{ Ave. weight of trees } \\
\hline & $g m$ & per cent* & $g m$ & per cent c $^{*}$ & $g m$ & per cent* & $g m$ & \multicolumn{2}{|c|}{ per cent* } \\
\hline & \multicolumn{9}{|c|}{ Peach-root composting materials } \\
\hline $\begin{array}{l}\text { Whole root } \\
\text { Dry ........ } \\
\text { Fresh...... }\end{array}$ & $\begin{array}{l}500 \\
\cdots\end{array}$ & $\begin{array}{r}70 \\
\cdots\end{array}$ & $\begin{array}{l}500 \\
\cdots\end{array}$ & $\begin{array}{l}110 \\
\cdots\end{array}$ & $\begin{array}{l}190 \\
\cdots\end{array}$ & $\begin{array}{r}98 \\
\cdots\end{array}$ & 350 & $\ddot{99}$ & $\begin{array}{l}\cdots \\
\cdots\end{array}$ \\
\hline $\begin{array}{l}\text { Wood } \\
\text { Dry........ } \\
\\
\text { Fresh....... } \\
\text { Steamed.... } \\
\text { Frozen ...... }\end{array}$ & $\begin{array}{l}306 \\
\cdots \\
\cdots \\
\cdots\end{array}$ & $\begin{array}{l}21 \\
\cdots \\
\cdots \\
\cdots\end{array}$ & $\begin{array}{l}100 \\
\cdots \\
\cdots \\
\cdots\end{array}$ & $\begin{array}{l}105 \\
\ldots \\
\cdots \\
\cdots\end{array}$ & $\begin{array}{l}\cdots \\
350\end{array}$ & $\begin{array}{l}\cdots \\
\cdots \\
\cdots \\
40\end{array}$ & $\begin{array}{l}190 \\
200 \\
350 \\
190 \\
\cdots\end{array}$ & $\begin{array}{r}80 \\
\cdots \\
93 \\
110 \\
\cdots\end{array}$ & $\begin{array}{l}\cdots \\
90 \\
\cdots \\
\cdots \\
\cdots\end{array}$ \\
\hline $\begin{array}{l}\text { Bark } \\
\text { Dry } \ldots . . . \ldots \\
\text { Powder ..... } \\
\text { Fresh ...... } \\
\text { Frozen } \ldots . .\end{array}$ & $\begin{array}{l}194 \\
194 \\
\cdots \\
\cdots\end{array}$ & $\begin{array}{r}89 \\
48 \\
\cdots \\
\cdots\end{array}$ & $\begin{array}{l}194 \\
194 \\
\cdots \\
\cdots\end{array}$ & $\begin{array}{l}110 \\
115 \\
\cdots \\
\cdots\end{array}$ & $\begin{array}{l}190 \\
190 \\
\cdots \\
\cdots\end{array}$ & $\begin{array}{r}104 \\
96 \\
\cdots \\
\cdots\end{array}$ & $\begin{array}{l}200 \\
190 \\
350 \\
350\end{array}$ & $\begin{array}{c}91 \\
\ldots \\
109 \\
\cdots\end{array}$ & $\begin{array}{c}\cdots \\
97 \\
\cdots \\
115\end{array}$ \\
\hline $\mathbf{A x} \ldots \ldots \ldots$ & 81 & 48 & 81 & 115 & 81 & 102 & $\cdots$ & $\cdots$ & $\cdots$ \\
\hline $\operatorname{RAx} \ldots \ldots \ldots$ & 112 & 49 & 112 & 105 & .. & $\cdots$ & 190 & $\cdots$ & 117 \\
\hline $\mathrm{BA} 1+\mathrm{BA} 2 \ldots$ & 58 & 33 & 58 & 110 & $\cdots$ & $\cdots$ & $\cdots$ & $\cdots$ & $\cdots$ \\
\hline BA3 $\ldots \ldots \ldots$ & 20 & 103 & $\cdots$ & $\cdots$ & $\ldots$ & $\ldots$ & $\cdots$ & $\cdots$ & $\cdots$ \\
\hline $\begin{array}{l}\text { Mean dry wt } \\
\text { Checks in gm }\end{array}$ & 5 & & 60 & $\mathrm{~m} \dagger$ & 44 & & & $43.0 \ddagger$ & \\
\hline
\end{tabular}

Other composting materials

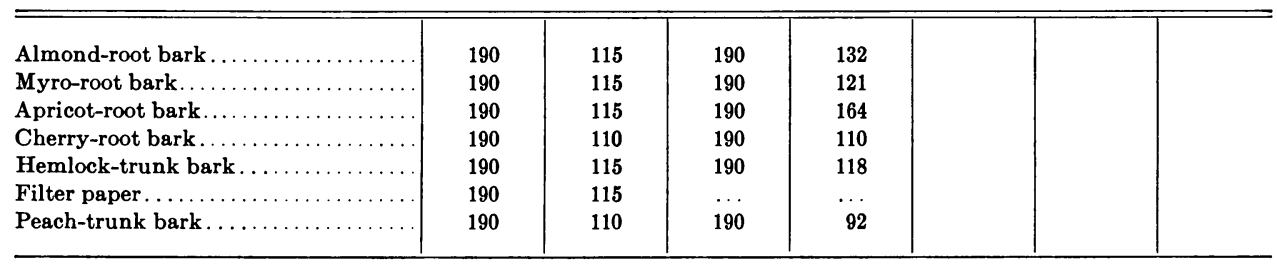

* Percentage of check.

$\ddagger$ Exclusive of steamed checks. 
Only 12 checks (soil 26) were used as this soil had become unavailable and only this amount of unused soil remained from the previous year's collection.

Table 7 shows the extremely poor growth of these seedlings regardless of treatment or condition. Though the two soils used were of different series no differences were noted in their behavior to replanting. The poor performance of the checks throws doubt on the validity of the results, but there is reason to believe that the poor performance of the checks-much worse than any of the others on a survival basis-was due to some condition peculiar to them; and that the poor growth of the remainder of the plants was the result of the previous cropping to peach. What this influence on the checks might have been is not known, but the possibility exists that since these pots of soil were stored outside the lathhouse from the time of collection the previous spring they may have been subjected to some herbicide used in weed control on the Experiment Station. In any event these pots showed a considerable degree of recovery the following season while the remainder did not.

Experiment 6: Experiment 6 (table 8) shows the results of replanting the pots of experiment 5 , and in addition the performance of seedlings the first planting in soil 27, newly introduced into the experiment. Again replants in soils 20 and 26 showed almost total inhibition. Growth in the 12 pots used as checks in experiment 5 was much better than in the previous year but by no means up to the potential of this soil. It is interesting to note that the growth in these pots the second year was inversely related to that occurring in the first. The six in which the first year trees had died immediately after transplanting produced an average weight of $31.1 \mathrm{gm}$ in the second year. Five pots which had produced seedlings weighing up to 5.5 gm from the first planting produced an average of $25.8 \mathrm{gm}$ their second and the single pot that first produced a $10.2 \mathrm{gm}$ seedling had only a $12.4 \mathrm{gm}$ seedling its second year.

Previously uncropped pots of soil 27 showed poor growth of the seedlings, as compared with first planting in soils 20 and 26 ; but, as will be seen, this was a normal performance for this soil.

Experiment 7: In experiment 7 (table 9 ), pots of soil 26 were treated in various ways in an attempt to correct their poor performance resulting from repeated cropping. The pots of soil 27 which were first cropped the previous year were similarly treated. With soil 26 , steaming was apparently of some benefit which, though great in relation to the untreated pots, still did not ap-

TABLE 7

REPLANTING AND TREATING EFFECTS ON AVERAGE DRY WEIGHT OF SEEDLING TOPS (SURVIVORS)

(Pot experiment 5)*

\begin{tabular}{|c|c|c|c|c|}
\hline Rank of set & Treatment & $\begin{array}{c}\text { Survivors } \\
\text { (Arithmetic } \\
\text { means) }\end{array}$ & $\begin{array}{l}\text { No. of } \\
\text { original } \\
\text { pots }\end{array}$ & Surviving \\
\hline 1 & Check. & $g m$ & $12 t$ & $\begin{array}{c}\text { per cent } \\
50\end{array}$ \\
\hline 2 & DD 5 cc.... & 5.7 & $24 \ddagger$ & 75 \\
\hline 3 & $\mathrm{CS}_{\mathbf{2}} 5 \mathrm{cc} \ldots \ldots \ldots$ & 5.0 & $24 \ddagger$ & 91.7 \\
\hline 4 & Not treated..... & 3.8 & $24 \ddagger$ & 83.3 \\
\hline 5 & White gasoline $15 \mathrm{cc} \ldots \ldots \ldots \ldots \ldots$ & 2.2 & $23 \S$ & 95.8 \\
\hline 6 & Previous year's roots alive $\ldots \ldots \ldots \ldots \ldots \ldots$ & 1.3 & $24 \ddagger$ & 91.7 \\
\hline
\end{tabular}

* Treatments applied to pots in which seedlings had previously been grown, 48 days before transplanting with 10-20 cm seedlings June 16, which were then grown 112 days in the lathhouse. No nitrogen applied.

$\dagger$ Soil 26 not previously cropped.

20 pots of soil 26 and 4 pots of soil 20.

$\$ 20$ pots of soil 26 and 4 pots of soil 20 . 
TABle 8

REPLANTING EFFECTS IN SOILS 20 AND 26, AND FIRST PLANTING IN SOIL 27 ON AVERAGE DRY WEIGHT OF SEEDLING TOPS (SURVIVORS)

(Pot experiment 6)*

\begin{tabular}{|c|c|c|c|c|c|}
\hline \multirow{2}{*}{$\begin{array}{l}\text { Rank } \\
\text { of set }\end{array}$} & \multicolumn{2}{|c|}{ Treatment } & \multirow{2}{*}{$\begin{array}{c}\text { Survivors } \\
\text { (Arithmetic } \\
\text { means) }\end{array}$} & \multirow{2}{*}{$\begin{array}{c}\text { Original } \\
\text { pots }\end{array}$} & \multirow{2}{*}{ Survival } \\
\hline & Cropping state & Soil & & & \\
\hline 1 & Checks of experiment 5 & 26 & $\begin{array}{c}g m \\
28.5\end{array}$ & $\begin{array}{c}\text { number } \\
12\end{array}$ & $\begin{array}{c}\text { per cent } \\
100\end{array}$ \\
\hline 2 & Not previously cropped. & 27 & 20.7 & 90 & $9 \mathrm{i}$ \\
\hline 3 & Cropped $2-3$ years. . . & 26 & 3.6 & 100 & 75 \\
\hline 4 & Cropped 4 years..... & 20 & 3.5 & 19 & 89.4 \\
\hline
\end{tabular}

* Transplanted with 15-25 cm seedlings May 11 and then grown 159 days in the lathhouse. Four gm ammonium nitrate per pot 17 days after transplanting.

TABLE 9

REPLANTING AND TREATING EFFECTS ON AVERAGE DRY

WEIGHT OF PEACH SEEDLINGS

(Pot experiment 7)*

\begin{tabular}{|c|c|c|c|}
\hline $\begin{array}{l}\text { Rank } \\
\text { of set }\end{array}$ & Treatment & $\underset{\text { means }}{\text { Arithm. }}$ & $\begin{array}{c}\text { No. of } \\
\text { pots }\end{array}$ \\
\hline \multicolumn{4}{|c|}{ Soil 26} \\
\hline $\begin{array}{l}1 \\
2 \\
3 \\
4 \\
5 \\
6 \\
7 \\
8 \\
9\end{array}$ & 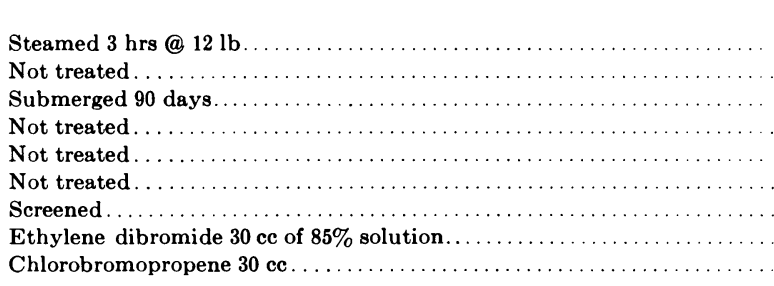 & \begin{tabular}{c}
\multicolumn{1}{c}{$g m$} \\
13.1 \\
7.1 \\
6.7 \\
6.1 \\
5.4 \\
4.7 \\
3.3 \\
3.2 \\
1.8
\end{tabular} & $\begin{array}{l}11 \\
11 \\
11 \\
11 \\
11 \\
11 \\
11 \\
11 \\
11\end{array}$ \\
\hline \multicolumn{4}{|c|}{ Soil 27} \\
\hline 1 & 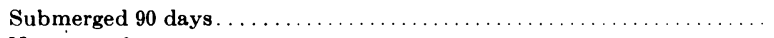 & 20.1 & 10 \\
\hline 2 & 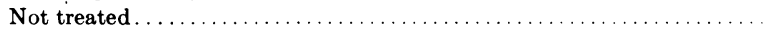 & 18.1 & 10 \\
\hline 3 & 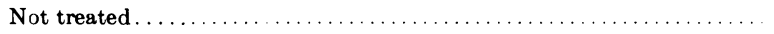 & 17.6 & 10 \\
\hline 4 & Not treated ................ & 16.8 & 10 \\
\hline 5 & 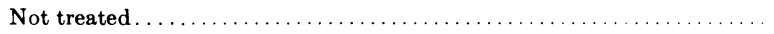 & 16.2 & 10 \\
\hline 6 & Check not previously cropped $\ldots \ldots \ldots \ldots \ldots \ldots \ldots \ldots \ldots \ldots \ldots \ldots \ldots \ldots \ldots \ldots$ & 16.3 & 10 \\
\hline 7 & 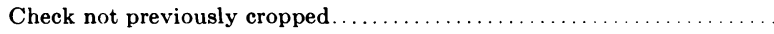 & 16.2 & 10 \\
\hline 8 & Ethylene dibromide $\mathbf{3 0}$ ec of $\mathbf{8 5} \boldsymbol{\%}$ solution $\ldots \ldots \ldots \ldots \ldots \ldots \ldots \ldots \ldots \ldots \ldots \ldots$ & 10.4 & 10 \\
\hline 9 & Screened $\ldots \ldots \ldots \ldots \ldots \ldots \ldots \ldots$ & 10.1 & 10 \\
\hline 10 & Steamed 3 hrs@ @12 lb... & 4.5 & 10 \\
\hline 11 & 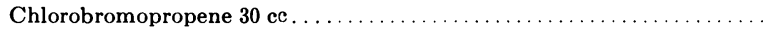 & 1.7 & 10 \\
\hline
\end{tabular}

* Previously cropped pots (12-20 cm seedlings) transplanted after treatments, June 6 and then grown 129 days in the lathhouse. No nitrogen applied. 
proach restoration of normal fertility. For soil 27 the same treatment apparently caused great harm. Chlorobromopropene was harmful to both soils probably because of incomplete removal even after the 15-day exposure period in trays. Ethylene dibromide may have been harmful and for the same reason. There is a suggestion that, for both soils, screening to remove the old root systems was harmful.

Experiment 8: In experiment 8, which is tabulated only as a part of table 10 arranged to show the successive yearly performance of selected replanted and treated pots, only two treatments were done. A set of each soil 26 and 27 were steamed at $15 \mathrm{lb}$ for 9 hours to check the results of the previous year's milder steamings at $12 \mathrm{lb}$ for 3 hours. The remainder of the sets were allowed to sprout and grow from the stumps. Three gm of calcium nitrate were added to each pot in July.

For soil 26 the more vigorous steaming gave added benefit. The production of this set was restored to approximately half that of the first planting. Steaming of soil 27 confirmed the harmful results of the previous year.

The growth of second-year shoots on the previous year's stumps is interesting. For soil 26 the sets 3 and 4 with which there had been no effective interference showed the weight of the second-year shoots to exceed that of the first by 3.4 times. For soil 27, which showed no apparent replant effect the second-year shoots from replanted sets 12,14 and 17 were only twice the weight of the first. The difference in ratios of first- to second-year shoots for the two soils being obviously due to the extremely poor first-year replant growth in soil 26. This difference in the relative performance of second-year shoots in the two soils is indicative of partial recovery, with time, of the depressed replantings in soil 26. This effect has been noted in the field (Gilmore, 1959). The beneficial effect of steaming and the apparent harmful effect of screening in experiment 7 is shown in the growth of second-year shoots in soil 26 .

For soil 27, which did not show the replant effect, the harmful effect of steaming was confirmed. Also in the growth of second-year shoots the harmful effects of the previous year's steaming was still apparent. Some effect of the previous year's screening apparently carried over but there was recovery from the ethylene dibromide treatment.

Harmful effects of screening out the old root systems, if such effects actually exist, are difficult to understand. It might be thought that a harmful organism could have been introduced by the screening process but since in the entire work no sanitary precautions were observed, and ample opportunity was present for cross transfer from pot to pot, this is unlikely. 
Table

COMPARISONS OF AVERAGE DRY WEIGHTS PRODUCED IN SUCCESSIVE YEARS

\begin{tabular}{|c|c|c|c|c|c|c|c|c|c|}
\hline \multirow[b]{2}{*}{$\begin{array}{l}\text { Set } \\
\text { no. }\end{array}$} & \multirow{2}{*}{$\begin{array}{l}\text { Pots } \\
\text { in } \\
\text { set }\end{array}$} & \multicolumn{2}{|c|}{ Experiment 2} & \multicolumn{2}{|c|}{ Experiment 3} & \multicolumn{2}{|c|}{ Experiment 4} & \multicolumn{2}{|c|}{ Experiment 5} \\
\hline & & $\begin{array}{l}\text { Preplantg. } \\
\text { treatment }\end{array}$ & $\begin{array}{l}\text { Dry wt. } \\
\text { of tops }\end{array}$ & $\begin{array}{l}\text { Preplantg. } \\
\text { treatment }\end{array}$ & $\begin{array}{l}\text { Dry wt. } \\
\text { of tops }\end{array}$ & $\begin{array}{l}\text { Preplantg. } \\
\text { treatment }\end{array}$ & $\begin{array}{l}\text { Dry wt. } \\
\text { of tops }\end{array}$ & $\begin{array}{l}\text { Preplantg. } \\
\text { treatment }\end{array}$ & $\begin{array}{l}\text { Dry wt. } \\
\text { of tops }\end{array}$ \\
\hline \multirow[b]{3}{*}{1} & \multirow[b]{3}{*}{10} & & $g m$ & & $g m$ & & $g m$ & & $g m$ \\
\hline & & \multicolumn{8}{|c|}{ Soil 20} \\
\hline & & Unknown & Est. 50 & Continu & growth & $\begin{array}{l}\text { Steam } 3 \mathrm{hrs} \\
@ 12 \mathrm{lb}\end{array}$ & 25.3 & $\begin{array}{c}\text { Various } \\
\text { fumigants }\end{array}$ & 6.2 \\
\hline \multirow[t]{2}{*}{2} & 10 & Unknown & Est. 50 & Continu & growth & Old roots alive & 6.9 & $\begin{array}{l}\text { Various } \\
\text { fumigants }\end{array}$ & 4.2 \\
\hline & & \multicolumn{8}{|c|}{ Soil 26} \\
\hline 3 & 11 & & & & & Various composts & 44.5 & $\begin{array}{c}\text { Various } \\
\text { fumigants }\end{array}$ & 3.8 \\
\hline 4 & 11 & & & & & Various composts & 39.3 & $\begin{array}{c}\text { Various } \\
\text { fumigants }\end{array}$ & 3.4 \\
\hline 5 & 11 & & & & & Various composts & 41.4 & $\begin{array}{c}\text { Various } \\
\text { fumigants }\end{array}$ & 1.4 \\
\hline 6 & 11 & & & & & Various composts & 47.5 & $\begin{array}{c}\text { Various } \\
\text { fumigants }\end{array}$ & 2.3 \\
\hline 7 & 11 & & & & & Check & 42.2 & $\begin{array}{c}\text { Various } \\
\text { fumigants } \\
\end{array}$ & 2.3 \\
\hline 8 & 11 & & & & & $\begin{array}{l}\text { Check steam } 3 \mathrm{hrs} \\
\text { (a) } 12 \mathrm{lb}\end{array}$ & 53.7 & $\begin{array}{c}\text { Various } \\
\text { fumigants }\end{array}$ & 6.8 \\
\hline 9 & 11 & & & Check & 44.8 & Old roots alive & 8.3 & $\begin{array}{r}\text { Various } \\
\text { fumigants }\end{array}$ & 2.0 \\
\hline 10 & 11 & & & Check & 46.4 & Old roots dead & 19.0 & $\begin{array}{c}\text { Various } \\
\text { fumigants }\end{array}$ & 1.6 \\
\hline \multirow[t]{2}{*}{11} & 12 & & & & & & & Check & 7.0 \\
\hline & & \multicolumn{8}{|c|}{ Soil 27} \\
\hline 12 & 10 & & & & & & & & \\
\hline 13 & 10 & & & & & & & & \\
\hline 14 & 10 & & & & & & & & \\
\hline 15 & 10 & & & & & & & & \\
\hline 16 & 10 & & & & & & & & \\
\hline 17 & 10 & & & . & & & & & \\
\hline 18 & 10 & & & & & & & & \\
\hline 19 & 10 & & & & & & & & \\
\hline
\end{tabular}

* 6 pots. 
10

IN SELECTED REPLANTED POTS, AND IN RESPONSE TO VARIOUS TREATMENTS

\begin{tabular}{c|c|c|c|c|c|c|c|}
\hline \hline \multicolumn{2}{c|}{ Experiment 6 } & Experiment 7 & Experiment 8 \\
\hline $\begin{array}{l}\text { Preplantg. } \\
\text { treatment }\end{array}$ & $\begin{array}{c}\text { Dry wt. } \\
\text { of tops }\end{array}$ & $\begin{array}{c}\text { Preplantg. } \\
\text { treatment } \\
\text { treatment }\end{array}$ & $\begin{array}{c}\text { Dry wt. } \\
\text { of tops } \\
\text { of tops }\end{array}$ & $g m$ & $g m$ \\
\hline
\end{tabular}

Soil 20

\begin{tabular}{l|l|l|l|l|}
\hline No treatments & 4.6 & No treatment & 3.2 & \\
\cline { 2 - 4 } No treatments & 2.5 & No treatment & 5.1 & \\
\hline
\end{tabular}

Soil 26

\begin{tabular}{|c|c|c|c|c|c|}
\hline No treatments & 3.1 & No treatment & 7.1 & No treatment 2nd year shoot & 22.4 \\
\hline No treatments & 3.0 & Submerged & 6.7 & No treatment 2nd year shoot & 24.8 \\
\hline No treatments & 3.1 & No treatment & 4.7 & Steam 9 hr@ 15 lb & 23.5 \\
\hline No treatments & 2.7 & Steam3 hrs@12 lb & 13.1 & No treatment 2nd year shoot & 39.5 \\
\hline No treatments & 4.7 & Chlorobromopropene $30 \mathrm{cc}$ & 1.8 & & \\
\hline No treatments & 6.8 & Screened & 3.3 & No treatment 2nd year shoot & 9.8 \\
\hline No treatments & 1.5 & $\begin{array}{l}\text { Ethylene dibromide } \\
30 \text { cc of } 85 \% \text { eslution }\end{array}$ & 4.3 & & \\
\hline No treatments & 3.8 & No treatment & 3.5 & & \\
\hline No treatments & 28.5 & No treatment & 10.9 & No treatment 2nd year shoot & 32.6 \\
\hline
\end{tabular}

Soil 27

\begin{tabular}{|c|c|c|c|c|c|}
\hline $\begin{array}{l}\text { Previously } \\
\text { uncropped }\end{array}$ & 20.2 & No treatment & 16.8 & No treatment 2nd year shoot & 40.1 \\
\hline $\begin{array}{l}\text { Previously } \\
\text { uncropped }\end{array}$ & 23.2 & Steam 3 hrs@ 12 lb & 4.5 & No treatment 2nd year shoot & 10.2 \\
\hline $\begin{array}{l}\text { Previously } \\
\text { uncropped }\end{array}$ & 16.2 & No treatment & 17.6 & No treatment 2nd year shoot & 33.3 \\
\hline $\begin{array}{l}\text { Previously } \\
\text { uncropped }\end{array}$ & 21.5 & $\begin{array}{l}\text { Ethylene dibromide } \\
30 \mathrm{cc} \text { of } 85 \% \text { solution }\end{array}$ & 10.4 & No treatment 2nd year shoot & 36.3 \\
\hline $\begin{array}{l}\text { Previously } \\
\text { uncropped }\end{array}$ & 18.4 & No treatment & 18.1 & Steam 9 hr@ 15 lb & 5.7 \\
\hline $\begin{array}{l}\text { Previously } \\
\text { uncropped }\end{array}$ & 22.1 & Submerged & 20.1 & No treatment 2nd year shoot & 35.6 \\
\hline $\begin{array}{l}\text { Previously } \\
\text { uncropped }\end{array}$ & 18.7 & Chlorobromopropene $30 \mathrm{cc}$ & 1.7 & No treatment 2nd year shoot & 6.7 \\
\hline $\begin{array}{l}\text { Previously } \\
\text { uncropped }\end{array}$ & 24.0 & Screened & 10.1 & No treatment 2nd year shoot & $25.3^{*}$ \\
\hline
\end{tabular}




\section{SUMMARY AND CONCLUSIONS}

Three of four experiments designed to simulate the peach replant effect in soil pot cultures by composting the soils with peach root substances failed. Peach-root wood sometimes gave depression in these experiments but nitrogen suppression due to stimulation of biological activity by the wood seemed to be the causative factor. In one experiment all peach-root substances except one (the sugar-glucoside fraction) gave some depression but nitrogen availability as a cause was suspected only in the peach-root wood fraction.
In two fertile soils used, the replant problem could be simulated by growing a seedling for a season, harvesting the top in such a way that the roots were killed and replanting with a new seedling the following season. Response of these soils to fumigants was poor. Fertility was only partly restored by steaming. Replanted seedlings in one of these soils gave evidence of partial recovery if they were allowed to continue growth a second year.

A third soil, less fertile than the others, did not show the replant effect but was severely injured by steaming.

\section{LITERATURE CITED}

Gilmore, A. E.

1950. A technique for embryo culture of peaches. Hilgardia 20 (8) :147-70.

1959. Growth of replanted peach trees. Proc. Amer. Soc. Hort. Sci. 73:99-111.

1962. Competition effects between peach seedlings in pots. Proc. Amer. Soc. Hort. Sci. 80:204-06.

Havis, Leon, and Anna L. Gilkinson

1947. Toxicity of peach roots. Proc. Amer. Soc. Hort. Sci. $50: 203-05$.

Hilderbrand, E. M.

1945. Peach root toxicity in a New York orchard. Plant Disease Reporter. 29(6):179.

Hirai, J., S. Nakagawa, and Y. Nanjo

1957. Growth of peach seedlings as related to the peach bark added to the soil and some other soil treatments. (In Japanese with English summary.) Studies from the Institute of Horticulture, Kyoto University. 8:32-37.

\section{Hirano, S.}

1957. Studies on peach sick soil. III. On the toxic substances in peach root. (In Japanese with English summary.) Studies from the Institute of Horticulture, Kyoto University 8:27-31.

Proebsting, E. L., and A. E. Gilmore

1940. The relation of peach root toxicity to the re-establishing of peach orchards. Proc. Amer. Soc. Hort. Sci. $38: 21-26$. 
The journal HILGARDIA is published at irregular intervals, in volumes of about 650 to 700 pages. The number of issues per volume varies.

Single copies of any issue may be obtained free, as long as the supply lasts; please request by volume and issue number from:

\author{
Agricultural Publications \\ University Hall \\ University of California \\ Berkeley 4, California
}

The limit to nonresidents of Califormia is $\mathbf{1 0}$ separate titles. The limit to California residents is $\mathbf{2 0}$ separate titles.

The journal will be sent regularly to libraries, schools, or institutions in one of the following ways:

1. In exchange for similar published material on research.

2. As a gift to qualified repository libraries only.

3. On a subscription basis $-\$ 7.50$ a year paid in advance. All subscriptions will be started with the first number issued during a calendar year. Subscribers starting during any given year will be sent back numbers to the first of that year and will be billed for the ensuing year the following January. Make checks or money orders payable to The Regents of The University of California; send payment with order to Agricultural Publications at above address. 